\title{
Study on bioremediation of soil contaminated with polychlorinated biphenyls (PCBs)
}

\section{Badania bioremediacji gleby zanieczyszczonej polichlorowanymi bifenylami (PCBs)}

\author{
Katarzyna Wojtowicz, Teresa Steliga \\ Oil and Gas Institute - National Research Institute
}

\begin{abstract}
The article presents issues related to biodegradation of polychlorinated biphenyls in soil by inoculation with a biopreparation IN-3 developed on the basis of microorganisms capable of metabolizing PCB. Biodegradation tests were carried out using the ex-situ technological pile method on a specially constructed test stand. As part of the research, physical and chemical analyzes of the initial soil were performed, with particular regard to the content of nutrients (nitrogen and phosphorus), PCB chromatographic analyzes and toxicological analyzes. Before inoculating soil with biopreparation IN-3, the parameters of the process were established (temperature $=17-25^{\circ} \mathrm{C}$, humidity $=20-25 \%, \mathrm{pH}=7.5-7.8$, content of nutrients: $\mathrm{C}: \mathrm{N}: \mathrm{P}=100: 10: 1$ ), which were monitored during bioremediation. During soil treatment, the content of identified PCB congeners was monitored. The assessment of biodegradation efficiency of polychlorinated biphenyls in soil was complemented by toxicological monitoring, which was carried out using live organisms representing all trophic levels: producers (Phytotoxkit ${ }^{\mathrm{TM}}$ test), consumers (Ostracodtoxkit $\mathrm{F}^{\mathrm{TM}}$ test) and reducers agents (Microtox ${ }^{\circledR} \mathrm{SPT}$ test). Also, the presence of mutagenic factors were tested with the Ames mutagenicity test. As a result of the six-month biodegradation process of soil contaminated with aged transformer oil, upon inoculation with biopreparation IN-3, a reduction in the content of polychlorinated biphenyls from $13153.9 \mu \mathrm{g} / \mathrm{kg}$ d.m. down to $1650.4 \mu \mathrm{g} / \mathrm{kg}$ d.m. (87.5\%) was archieved. The obtained chromatographic analysis results showed that the efficiency of the PCB biodegradation depended on the number of chlorine atoms in the biphenyl ring (with the increase in the number of chlorine atoms in the PCB molecule the degree of biodegradation decreased) and the structure of the molecule (PCB congeners having 2 or more chlorine atoms in the biphenyl ring ortho positions were more difficult to biodegrade than non-ortho or mono-ortho, while polychlorinated biphenyls, in which chlorine atoms occur on only one phenyl ring, were more easily biodegradable). The toxicological analysis showed a reduction in the toxicity of the soil tested from toxicity unit TU $=26.7$ to $\mathrm{TU}=6.1$. In addition, toxkit tests (Phytotoxkit ${ }^{\mathrm{TM}}$ and Ostracodtoxkit $\mathrm{F}^{\mathrm{TM}}$ ) showed a decrease in inhibition of test organism growth from 69.3 to $14.8 \%$ (Ostracodtoxkit $\mathrm{F}^{\mathrm{TM}}$ test) and from $64.7-78.0$ to $11.9-17.5 \%$ (Phytotoxkit test). Decreasing the mutagenicity index from 8.3 to 1.5 in the Ames test confirmed the effectiveness of the purification process. Based on the results of the experiment, conclusions were made regarding issues related to biodegradation of polychlorinated biphenyls in soil.
\end{abstract}

Key words: biodegradation, polychlorinated biphenyls, soil, chromatographic analysis, toxicological tests.

STRESZCZENIE: W artykule przedstawiono zagadnienia związane $\mathrm{z}$ biodegradacją polichlorowanych bifenyli w glebie w drodze inokulacji biopreparatem IN-3, opracowanym na bazie mikroorganizmów zdolnych do metabolizowania PCB. Badania biodegradacji prowadzono metodą pryzmowania ex-situ na specjalnie do tego celu skonstruowanym stanowisku badawczym. W ramach prowadzonych badań wykonano analizy fizyczno-chemiczne gleby wyjściowej, ze szczególnym uwzględnieniem zawartości substancji biogennych (azot i fosfor), analizy chromatograficzne PCB oraz analizy toksykologiczne. Przed przystąpieniem do inokulacji gleby biopreparatem ustalono parametry prowadzenia procesu (temperatura $=17-25^{\circ} \mathrm{C}$, wilgotność $=20-25 \%, \mathrm{pH}=7,5-7,8$, zawartość substancji biogennych: $\mathrm{C}: \mathrm{N}: \mathrm{P}=100: 10: 1)$, które kontrolowano $\mathrm{w}$ trakcie bioremediacji. $\mathrm{W}$ trakcie oczyszczania gleby prowadzono monitoring zawartości zidentyfikowanych kongenerów PCB. Ocenę skuteczności biodegradacji polichlorowanych bifenyli w glebie rozszerzono o monitoring toksykologiczny, który przeprowadzono przy użyciu żywych organizmów reprezentujących wszystkie poziomy troficzne: producentów (test Phytotoxkit ${ }^{\mathrm{TM}}$ ), konsumentów (test Ostracodtoxkit $\mathrm{F}^{\mathrm{TM}}$ ) i reducentów (test Microtox ${ }^{\circledR} \mathrm{SPT}$ ), a także wykonano badania obecności czynników mutagennych (test Amesa). W wyniku przeprowadzonego sześciomiesięcznego procesu biodegradacji gleby zanieczyszczonej zestarzałym olejem transformatorowym, na drodze inokulacji biopreparatem IN-3, osiągnięto obniżenie zawartości polichlorowanych bifenyli z $13153,9 \mu \mathrm{g} / \mathrm{kg} \mathrm{s.m.} \mathrm{do} \mathrm{1650,4} \mu \mathrm{g} / \mathrm{kg}$ s.m. (87,5\%). Uzyskane wyniki analiz chromatograficznych wykazały, że efektywność biodegradacji PCB zależy od liczby atomów chloru w pierścieniu bifenylu (wraz ze wzrostem liczby atomów chloru w cząsteczce PCB maleje stopień biodegradacji) oraz budowy przestrzennej cząsteczki (kongenery PCB posiadające

Coressponding author: K. Wojtowicz, e-mail: katarzyna.wojtowicz@inig.pl

Article contributed to the Editor: 04.12.2019. Approved for publication: 09.07.2020 
w pierścieniu bifenylu dwa lub więcej atomów chloru w pozycji ortho trudniej ulegają biodegradacji, aniżeli non-ortho lub mono-ortho, z kolei polichlorowane bifenyle, w których atomy chloru występują tylko na jednym pierścieniu fenylowym, są łatwiej biodegradowalne). Przeprowadzona analiza toksykologiczna wykazała obniżenie toksyczności badanej gleby ze stopnia toksyczności TU $=26,7$ do $\mathrm{TU}=6,1$. Ponadto testy typu toxkit (Phytotoxkit ${ }^{\mathrm{TM}}$ i Ostracodtoxkit $\mathrm{F}^{\mathrm{TM}}$ ) wykazały obniżenie zahamowania wzrostu organizmów testowych z $69,3 \%$ do $14,8 \%$ (test Ostracodtoxkit $\mathrm{F}^{\mathrm{TM}}$ ) oraz z poziomu 64,7-78,0\% do 11,9-17,5\% (test Phytotoxkit ${ }^{\mathrm{TM}}$ ). Obniżenie wskaźnika mutagenności z 8,3 do 1,5 w teście Amesa potwierdziło skuteczność przeprowadzonego procesu oczyszczania. Na podstawie uzyskanych wyników przeprowadzonego eksperymentu sformułowano wnioski dotyczące zagadnień związanych z biodegradacją polichlorowanych bifenyli w glebie.

Słowa kluczowe: biodegradacja, polichlorowane bifenyle, gleba, analiza chromatograficzna, testy toksykologiczne.

\section{Introduction}

The progressing urbanisation as well as development of numerous sectors of industry, agriculture or mining resulted in recent decades in significant pollution of the natural environment. The soil environment is particularly exposed to contamination both with organic and inorganic substances, which occurs most frequently as a result of spot spillage or leakage of hazardous substances, or due to the pollution emission from such sources as means of transport, industrial plants, industrial and municipal waste landfills. The most important soil pollutants include aliphatic hydrocarbons, aromatic hydrocarbons: $\mathrm{PAH}$ and BTEX, polychlorinated biphenyls, pesticides, and heavy metals.

Polychlorinated biphenyls are biphenyl synthetic chlorinated compounds, which due to their chemical properties (such as stability, lack of conductivity, and non-flammability) were widely used in industry, especially as transformer oil components. In the natural environment the PCB group compounds feature high resistance to the action of both biotic and abiotic factors. They do not hydrolyse, are resistant to acids and alkalis, and are difficult to biodegrade (Sobielska, 2009). Because of their toxicity they cannot be used in Poland since 2010. As many as 209 PCB varieties are known (referred to as congeners), differing in the number of chlorine atoms and the place of their substitution in phenyl rings. After getting to the natural environment PCBs create a hazard not only to humans, but also to a number of other organisms.

The cleaning of soils polluted with PCBs using conventional methods such as dechlorination, thermal methods, pollutions after-combustion, soil washing or the plasma method, are most often too expensive. Biological methods (Leigh et al., 2006; Atago et al., 2016) are an alternative strategies for PCBs removal from the soil. Because of that fact the development of effective methods for soils remediation using microorganisms capable of PCB metabolism became extremely important. The first report on possibilities to use bacterial organisms to biodegrade PCBs was published in 1970 (Lunt and Evans, 1970). Ever since, because of permanently growing needs to develop effective cleaning methods for soils contaminated with polychlorinated biphenyls, continuous development of biodegradation techniques has been observed (Wang et al., 2016; Pathiraja et al., 2019).

The effectiveness of PCB biodegradation is to a large extent related to the presence of appropriate cultures of microorganisms capable of using polychlorinated biphenyls as a source of carbon and energy in metabolic processes. Microorganisms used in the process of biological PCBs degradation should feature such properties as: tolerance to $\mathrm{PCBs}$, capacity to produce surfactants, increased PCBs availability, capacity to produce enzymes responsible for dechlorination of PCBs, degradation of pollutants without or with minimum production of toxic intermediate products as well as capability of surviving till the end of cleaning (Furukawa and Fujihara, 2008). The most active bacteria capable of PCBs metabolizing and most frequently reported in the literature include: Achromobacter sp. (Dudášová et al., 2014; Blanco-Moreno et al., 2017), Acinetobacter sp. (Liang et al., 2014), Bacillus sp. (Suyamud et al., 2018), Burkholderia sp. (Ponce et al., 2011) Janibacter sp. (Sierra et al., 2003), Mycobacterium sp. (Shleeva et al., 2002), Pseudomonas sp. (Mouhamadou et al., 2013; Chakraborty and Das, 2016; Suenaga et al., 2017), and Rhodococcus sp. (Chung et al., 1994; Shumkova et al., 2015; Atago et al., 2016). Frequently selected fungi, capable of decomposing chemical compounds with complicated structures, are added to bacterial biopreparations to increase the efficacy of PCBs biodegradation (Čvančarová et al., 2012). The world literature presents a number of studies on polychlorinated biphenyls biodegradation with the use of the following fungi: Aspergillus sp., (Kim et al., 2016), Doratomyces sp., (Mouhamadou et al., 2013), Mesorhizobium sp. (Teng et al., 2016), and Penicillum sp. (Siracusa et al., 2017; Stella et al., 2017). Moreover, in recent years the remediation methods that make use of, utilising natural activity of plants to collect components polluting the natural environment, become increasingly important in restoring application values of soils (Li et al., 2011; Lu et al., 2014).

Apart from biological factors the effectiveness of biodegradation of pollutants from the PCBs group is affected by environmental factors, such as $\mathrm{pH}$, humidity, oxygen presence, 
temperature, nutrients content, soil matrix properties (Wu et al., 2017; Steliga et al., 2018a), an addition of a surfactant (Lászlová et al., 2018) as well as pollution related factors (physical and chemical properties of polychlorinated biphenyls, number of chlorine atoms in a biphenyl ring, pollutant age, xenobiotic concentration, and a spatial PCB structure) (Passatore et al., 2014).

The study was aimed at carrying out tests of polychlorinated biphenyls (PCBs) biodegradation in a soil polluted with a transformer oil under semi-technical conditions (by means of the ex-situ technological pile method) with the use of a biopreparation IN-3 containing selected bacterial strains capable of PCBs biodegradation. The efficiency of PCB biodegradation in the soil was assessed by means of thorough monitoring by, applying chromatographic determinations of individual polychlorinated biphenyls contents. An important aspect of the tests consisted in performing toxicological monitoring during bioremediation, using a package of new generation toxicological tests, which allowed to enable a comprehensive assessment of the tested soil environment condition.

\section{Experimental studies}

\section{Description of a stand for PCBs biodegradation tests under ex-situ laboratory conditions}

Tests of polychlorinated biphenyls biodegradation under laboratory - semitechnical conditions were carried out by means of ex-situ technological pile method on a specially designed test stand. To protect the room against contamination an insulating foil was spread on the floor, on which a stand was placed, which design enabled drainage of water surplus and of liquid pollutants from the pile to the effluents tank. On the stand a layer of gravel bedding was placed, inside which a system of perforated pipes was situated, through which air from a compressor was pumped for proper aeration of soil during the biodegradation. Then a pile (approx. $50 \mathrm{~kg}$ ) was formed from the soil polluted with aged transformer oil containing PCBs and it was covered with a foil tunnel, which allowed for maintaining a constant temperature inside the pile, ranging from 17 to $25^{\circ} \mathrm{C}$. During the process of cleaning a constant humidity was maintained, within 20-25\%, while the $\mathrm{pH}$ was stabilised at approx. 7.5-7.8, batching the fertilizer lime. Optimum proportions of biogenic substances $\mathrm{N}: \mathrm{P}=10: 1$ for the studied soil, were chosen by gradual proportioning of biogenic substances (nitrogen and phosphorus) in the form of 'Azofoska' mineral fertilizer. The process of inoculation was carried out by sprinkling the technologicalpile with biopreparation IN-3 Biopreparation IN-3 was composed of the strains Rhodococcus erythropolis IN104 and Rhodococcus sp. IN306 at biomass ratio 1:2 (density each strain in biopreparation IN-3 was $1 \cdot 10^{8}-1 \cdot 10^{9} \mathrm{CFU} \cdot \mathrm{ml}^{-1}$ ). The 16S rDNA sequences of these strains have been deposited in the NCBI GenBank database and are available under the following accession numbers: KT923338 (Rhodococcus erythropolis IN104) and KX058399 (Rhodococcus sp. IN306). The IN104 and IN306 strains have ability to metabolize biphenyl and its derivatives. Moreover Rhodococcus sp. IN306 strain is very closely related to the Rhodococcus jostii RHA-1 species, which is a well-known degrader of biphenyl and its polychlorinated derivatives (Brzeszcz, 2017).

During the soil bioremediation through inoculation with biopreparation IN-3 developed based on microorganisms capable of PCBs metabolizing, the content of biogenic substances (nitrogen and phosphorus compounds), concentration of polychlorinated biphenyls, and the soil toxicity were monitored.

Figure 1 presents a scheme of the test stand used during the PCBs biodegradation in a contaminated soil on a laboratory - semi-technical scale (by means of the ex-situ method).

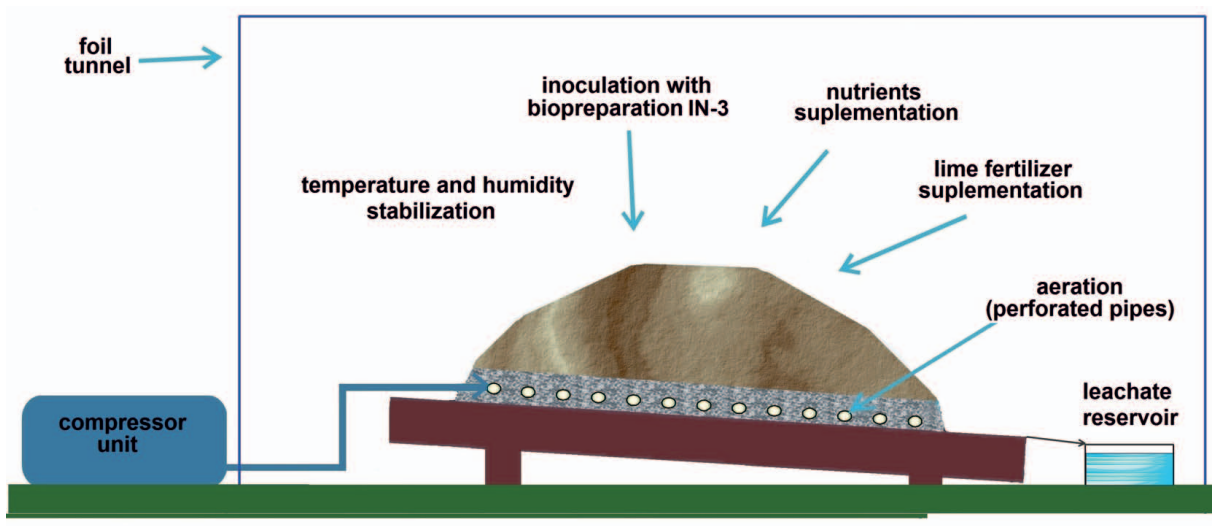

Fig. 1. Scheme of the test stand for conducting the process of biodegradation of pollutants (PCBs) in soil under semi-technical conditions (ex situ technological pile method)

Rys. 1. Schemat stanowiska badawczego do prowadzenia procesu biodegradacji zanieczyszczeń (PCB) w glebie w warunkach półtechnicznych (metoda pryzmowania ex situ)

\section{Chromatographic analysis of PCBs}

The main element enabling determination of efficiency of PCB pollutants biodegradation in the carried out processes of soil cleaning by the ex-situ method consisted in the use of chromatographic methods for studied xenobiotics determination in the soil. Because of a complex nature of the soil matrix it was necessary to carry out a complicated and time-consuming stage of sample preparation. The procedure of sample preparation for chromatographic analysis was performed based on previous studies (Kania-Korwel and Lehmler, 2016; Wojtowicz and Jakubowicz, 2019), comprising: sampling and preliminary 
sample preparation, extraction of analytes from the matrix (extraction by a mixture of n-hexane and dichloromethane at 1:1 ratio), sample cleaning from interfering substances (extraction to an SPE solid phase with the use of Bakerbond Silica gel columns No 7086-03 and PCB-A No 7511).

The method of gas chromatography with ECD detection was applied to determine polychlorinated biphenyls occuring in the studied soil, comprising identification of analytes and quantitative determination of PCB congeners. The chromatographic analysis was carried out on a Perkin Elmer Clarus 500 chromatograph, equipped with a Restek capillary column RTX-XLB $(30 \mathrm{~m} \times 0.32 \mu \mathrm{m})$, using the following temperature parameters: injector temperature $=280^{\circ} \mathrm{C}, \mathrm{ECD}$ detector temperature $=320^{\circ} \mathrm{C}$, oven temperature programme: $120^{\circ} \mathrm{C}$ - isothermal course for $2 \mathrm{~min}$., $120-280^{\circ} \mathrm{C}$ - temperature increase at a rate of $15^{\circ} \mathrm{C} / \mathrm{min} ., 280^{\circ} \mathrm{C}$ - isothermal course for $5 \mathrm{~min}$., $280-320^{\circ} \mathrm{C}$ - temperature increase at a rate of $28^{\circ} \mathrm{C} / \mathrm{min} ., 320^{\circ} \mathrm{C}-$ isothermal course for $10 \mathrm{~min}$. (Wojtowicz and Jakubowicz, 2019). A certified Sigma-Aldrich PCB Congeners in Soil SQC068-50g standard of sterile soil was used for qualitative and quantitative determination of individual PCB congeners.

\section{Toxicological analysis}

The effectiveness of biodegradation processes carried out in the soil, parallel to determination of toxicant (PCBs) concentration, was assessed based on results of toxicological tests. Soil samples were analysed using 3 micro-biotests with organisms belonging to three trophic levels: producers; Phytotoxkit ${ }^{\mathrm{TM}}$ (Maminidy-Pajany et al., 2011; Blinova et al., 2012; Baran and Tarnawski, 2013), consumers; Ostracodtoxkit $\mathrm{F}^{\mathrm{TM}}$ (Niyommaneerat et al., 2017, Steliga et al., 2018b), reducers; Microtox ${ }^{\circledR}$ STP (Lima et al., 2011; Slater et al., 2011; TruszZdybek et al., 2012; Foucaulty et al., 2013; Oleszczuk et al., 2014; Oh et al., 2015) and additional mutagenicity test Ames (Steliga et al., 2012; Vijay et al., 2018).

The chronic toxicity assessment test Phytotoxkit ${ }^{\mathrm{TM}}$ is based on the assessment of plants germination and early growth (root elongation inhibition measurement), which is standardised in accordance with a Polish standard (PN-ISO 11269-1:1998). Three types of plants are used in the test, selected on the basis of the germination rate and root growth rate, enabling performance of full determination during 3 days of incubation: monocotyledonous sorghum (Sorghum saccharatum), dicotyledonous cress (Lepidium sativum), and mustard (Sinapis alba). Determinations were carried out in three repetitions for each test plant. Tests were performed in polystyrene transparent test plates. Incubation conditions: temperature $\mathrm{T}=25^{\circ} \mathrm{C}$ in the dark, incubation time $\mathrm{t}=72 \mathrm{~h}$. Test reaction: germination and early root growth inhibition (Steliga and Kluk, 2019).
The chronic toxicity assessment test Ostracodtoxkit $\mathrm{F}^{\mathrm{TM}}$ uses young bottom living crustaceans Heterocypris incongruens hatched from spore cysts within 52 hours. After 6 days of contact with the tested deposits their percentage of mortality is determined as well as growth inhibition with respect to results obtained in contact with non-toxic control deposit. The test is carried out on plates with 6 wells $(3 \times 2)$, incubation time: 6 days at a temperature of $25^{\circ} \mathrm{C}$ (Steliga and Kluk, 2019).

Microtox ${ }^{\circledR} /$ DeltaTox - an acute toxicity test is based on measurement of Vibrio fischeri bacteria fluorescence, which under normal conditions use approx. $10 \%$ of metabolism to produce light. In the electron transport system of these bacteria, the luciferase enzyme (alkane oxygenase) catalyses the oxidation of reduced substrate (reduced flavin mononucleotide, flavin mononucleotide, or flavin-adenine dinucleotide), and during this process luminescence occurs, which can be measured by means of a photometer. The created substances involved in this reaction are oxygen and long chain aldehyde. At the presence of substances having a negative impact on cell metabolism bacteria very quickly respond with a decline of luminescence, which after 15 minutes of contact with the sample is measured by means of a Delta Tox analyser (Steliga and Kluk, 2019). Toxicity results were calculated as $\mathrm{EC}_{50}$, that is such a concentration of the studied sample, causing origination generations of $50 \%$ of test - survival reaction $(\mathrm{PE})$. Then the $\mathrm{EC}_{50}$ values were converted to toxicity units (TU) according to the formula (1):

$$
T U=\frac{100}{E C_{50}}
$$

The Ames test consists in detecting reverse mutations from histidine auxotrophy to prototrophy in numerous Salmonella typhimurium strains. Test strains of this bacterium feature various mutation types in genes responsible for histidine synthesis, due to which they require its presence in the medium to grow. Two standard tester strains TA98 and TA100 are used, having appropriate mutations consisting in so-called reading frame shift and base-pair substitution and two mutagens, i.e. 2-nitrofluorene and sodium azide. At the presence of a substance with mutagenic properties the first mutation occurs (through reversion) and the histidine synthesis capability is restored, which is manifested by the generation of revertants on the substrate without histidine. The number of revertants is a measure of the studied sample mutagenic activity.

\section{Characteristics of the studied material}

The studies on the PCB biodegradation were carried out on a soil polluted with an aged PCB-containing transformer 
oil (soil $\mathrm{G}$ ). In the process of soil cleaning through bioaugmentation carried out under ex-situ conditions biopreparation IN-3 was applied, developed at the Microbiology Department of INiG - PIB based on selected bacterial strains capable of PCB metabolism.

The performed physical and chemical analysis of the soil showed that in the sample intended for bioremediation there were no favourable conditions for the bacterial flora growth, because the $\mathrm{N}: \mathrm{P}$ ratio differed from the optimal one, while $\mathrm{pH}$ was 5.48. A proper choice of biogenic substances and determination of their concentrations in the soil prior to starting the bioremediation is extremely important and allows for enrichment of the environment with nutrients and for optimising parameters of the process course, where for proper activity of microorganisms the $\mathrm{C}: \mathrm{N}: \mathrm{P}$ ratio should be approx. 100:10:1 (Nwankwegu et al., 2016; Wu et al., 2017; Steliga et al., 2018a). Because of the above fact, prior to the start of soil inoculation with biopreparation IN-3 the soil $\mathrm{pH}$ and proportions of biogenic substances were adjusted and enriched with biogenic components (fortilizer lime and mineral fertilizer "Azofoska").

Large amounts of petroleum substances were determined in the tested soil: $\mathrm{TPH}=36126.1 \mathrm{mg} / \mathrm{kg}$ of dry mass, $\mathrm{BTEX}=3.7 \mathrm{mg} / \mathrm{kg}$ d.m., PAH $=0.9 \mathrm{mg} / \mathrm{kg}$ d.m. In addition, the carried out analyses showed an increased level of polychlorinated biphenyls PCB $=13153.9 \mu \mathrm{g} / \mathrm{kg}$ of dry mass. The percentage share of the identified PCB congeners in the soil intended for biodegradation by the ex-situ prism method is presented in Figure 2.

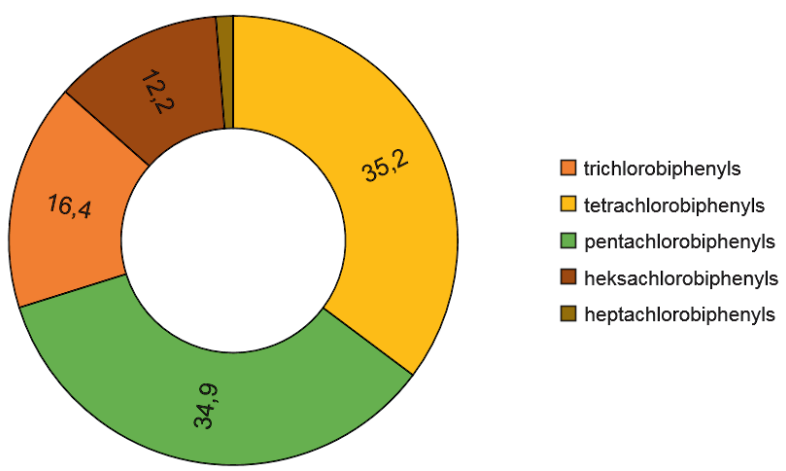

Fig. 2. Percentage of identified PCB congeners in the tested soil sample

Rys. 2. Procentowy udział zidentyfikowanych kongenerów PCB w badanej próbce gleby

\section{Discussion of PCBs biodegradation results (ex-situ method)}

The course of PCBs group pollutants biodegradation was controlled by means of monitoring selected physical and chemical parameters, with particular emphasis on the PCBs chromatographic analyses. The monitoring of content changes for identified PCB congeners was carried out during 6 months, collecting soil test samples every month (Soil G1, Soil G2, Soil G3, Soil G4, Soil G5, Soil G6) (Fig. 3).

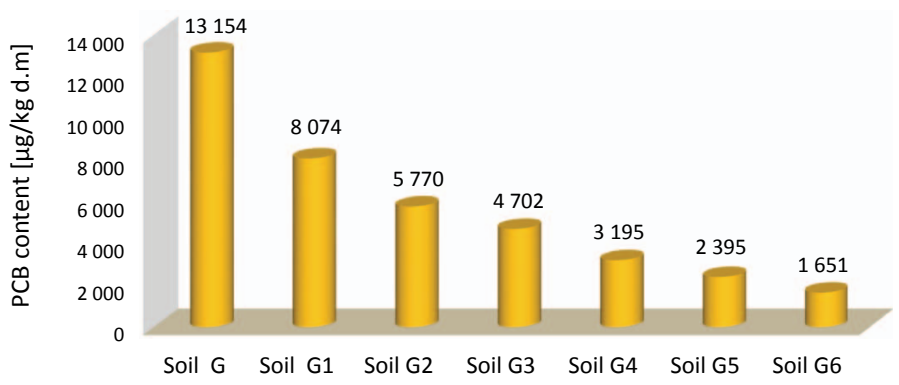

Fig. 3. Comparison of changes in PCB content during soil bioremediation by the ex-situ technological pile method

Rys. 3. Porównanie zmian zawartości PCB w trakcie bioremediacji gleby metodą pryzmowania ex-situ

The carried out laboratory tests (ex-situ conditions) showed that as a result of soil inoculation with biopreparation IN-3 after 6 months of the biodegradation the content of identified PCBs was reduced from $13153.9 \mu \mathrm{g} / \mathrm{kg}$ of dry mass to $1650.5 \mu \mathrm{g} / \mathrm{kg}$ d.m. The PCBs biodegradation was the most intensive during the first month $(38.6 \%)$, in the next months the biodegradation pace was going down and at the end it remained on a similar level.

The developed methodology for PCBs chromatographic determination in soils enables identifying individual PCB congeners, which allows for assessment of their biodegradation during biodegradation. The performed chromatographic analyses showed that the reduction of low-chlorinated biphenyls content: PCB28, PCB52, and PCB77 after a month of inoculation was: $50.0 \%$ (from 2152.8 to $1077.0 \mu \mathrm{g} / \mathrm{kg} \mathrm{d.m.),} 41.7 \%$ (from 4247.1 to $2474.4 \mu \mathrm{g} / \mathrm{kg}$ d.m.), and $45.4 \%$ (from 386.1 to $210.7 \mu \mathrm{g} / \mathrm{kg}$ ), respectively. The biodegradation of pentachlorobiphenyls was similar and ranged from 34.5 to $34.9 \%$. In this case the di-ortho PCB101 was an exception, whose biodegradation degree was much lower and after a month of the process amounted to $32.3 \%$. Among hexachlorobiphenyls the di-ortho PCB138 turned out most durable, for which the content reduction was from 607.6 to $435.0 \mu \mathrm{g} / \mathrm{kg}$ d.m., which is $28.4 \%$, and PCB156 from 145.6 to $101.4 \mu \mathrm{g} / \mathrm{kg}$ d.m., which is $28.9 \%$. The other congeners having 6 chlorine atoms in the molecule were reduced by 30.5 to $30.6 \%$. The PCB 180 congener, which has 7 chlorine atoms in a molecule and the di-ortho spatial structure, turned out to be definitely most difficult to biodegrade. Its biodegradation degree after a month of cleaning was only $20.2 \%$ (Table 1 ).

The course of polychlorinated biphenyls biodegradation in the next months of the process was similar, but its pace was decreasing and at the end it was on a similar level, e.g. 
Table 1. Comparison of changes in the content of identified PCB congeners during soil bioremediation by the ex-situ technological pile Tabela 1. Porównanie zmian zawartości zidentyfikowanych kongenerów PCB w trakcie bioremediacji gleby metodą pryzmowania ex-situ

\begin{tabular}{|c|c|c|c|c|c|c|c|c|}
\hline \multirow{2}{*}{ 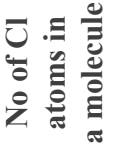 } & \multirow{2}{*}{ Symbol } & Soil G & Soil G1 & Soil G2 & Soil G3 & Soil G4 & Soil G5 & Soil G6 \\
\hline & & [ $\mu \mathrm{g} / \mathrm{kg}$ d.m.] & [ $\mu \mathrm{g} / \mathrm{kg}$ d.m.] & 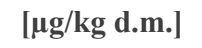 & 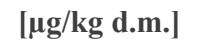 & [ $\mu \mathrm{g} / \mathrm{kg}$ d.m.] & 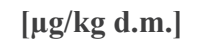 & [ $\mu \mathrm{g} / \mathrm{kg}$ d.m.] \\
\hline 3 & РCB28 & $\mathbf{2 1 5 2 . 8} \pm 107.5$ & $\mathbf{1 0 7 7 . 0} \pm 53.8$ & $\mathbf{5 3 9 . 5} \pm 27.0$ & $\mathbf{3 3 6 . 1} \pm 16.8$ & $\mathbf{2 1 7 . 5} \pm 10.9$ & $\mathbf{1 3 6 . 5} \pm 13.6$ & $\mathbf{9 0 . 0} \pm 9.0$ \\
\hline \multirow{2}{*}{4} & PCB52 & $\mathbf{4 2 4 7 . 1} \pm 212.4$ & $\mathbf{2 4 7 4 . 4} \pm 123.7$ & $\mathbf{1 7 5 7 . 4} \pm 87.9$ & $\mathbf{1 3 4 7 . 1} \pm 67.3$ & $995.1 \pm 49.8$ & $737.5 \pm 36.9$ & $499.0 \pm 24.9$ \\
\hline & PCB77 & $\mathbf{3 8 6 . 1} \pm 19.4$ & $\mathbf{2 1 0 . 7} \pm 10.5$ & $127.6 \pm 12.7$ & $\mathbf{1 0 8 . 1} \pm 10.8$ & $71.8 \pm 7.2$ & $\mathbf{4 5 . 3} \pm 4.5$ & $32.2 \pm 3.3$ \\
\hline \multirow{5}{*}{5} & PCB101 & $1664.8 \pm 83.2$ & $\mathbf{1 1 2 7 . 4} \pm 56.4$ & $\mathbf{8 7 3 . 3} \pm 43.6$ & $765.6 \pm 38.2$ & $\mathbf{5 0 0 . 5} \pm 25.0$ & $\mathbf{4 0 2 . 0} \pm 20.1$ & $272.2 \pm 13.6$ \\
\hline & PCB105 & $905.2 \pm 45.3$ & $\mathbf{5 8 9 . 2} \pm 29.4$ & $423.9 \pm 21.1$ & $\mathbf{3 4 2 . 0} \pm 17.1$ & $\mathbf{2 4 0 . 3} \pm 12.0$ & $179.2 \pm 9.0$ & $122.7 \pm 12.3$ \\
\hline & PCB114 & $\mathbf{1 0 7 . 5} \pm 10.8$ & $\mathbf{7 0 . 5} \pm 7.05$ & $\mathbf{5 3 . 7} \pm 5.4$ & $49.0 \pm 4.9$ & $28.6 \pm 2.8$ & $\mathbf{2 1 . 9} \pm 2.2$ & $\mathbf{1 5 . 0} \pm 1.5$ \\
\hline & PCB118 & $\mathbf{1 5 6 3 . 4} \pm 78.1$ & $\mathbf{1 0 2 1 . 6} \pm 51.1$ & $\mathbf{7 8 1 . 2} \pm 39.0$ & $667.2 \pm 33.3$ & $\mathbf{4 1 9 . 4} \pm 21.0$ & $\mathbf{3 1 2 . 4} \pm 15.6$ & $\mathbf{2 1 5 . 5} \pm 10.8$ \\
\hline & PCB123 & $354.4 \pm 17.7$ & $\mathbf{2 3 0 . 8} \pm 11.5$ & $170.7 \pm 8.5$ & $163.0 \pm 8.1$ & $\mathbf{9 8 . 1} \pm 9.7$ & $67.3 \pm 6.7$ & $\mathbf{4 8 . 1} \pm 4.8$ \\
\hline \multirow{5}{*}{6} & PCB138 & $\mathbf{6 0 7 . 6} \pm 30.4$ & $\mathbf{4 3 5 . 0} \pm 21.7$ & $\mathbf{3 5 4 . 1} \pm 17.7$ & $\mathbf{3 1 2 . 1} \pm 15.6$ & $\mathbf{2 0 6 . 2} \pm 10.3$ & $\mathbf{1 6 0 . 0} \pm 7.9$ & $\mathbf{1 1 3 . 8} \pm 11.4$ \\
\hline & PCB153 & $727.9 \pm 36,4$ & $\mathbf{5 1 7 . 3} \pm 17.2$ & $\mathbf{4 2 4 . 5} \pm 21.1$ & $374.2 \pm 18.7$ & $\mathbf{2 4 2 . 1} \pm 12.1$ & $191.4 \pm 9.6$ & $\mathbf{1 3 1 . 8} \pm 13.2$ \\
\hline & PCB156 & $\mathbf{1 4 5 , 6} \pm 14.5$ & $101.1 \pm 6.7$ & $79.8 \pm 7.9$ & $71.5 \pm 7.2$ & $\mathbf{4 5 . 0} \pm 4.5$ & $\mathbf{3 0 . 6} \pm 3.0$ & $23.4 \pm 2.4$ \\
\hline & PCB157 & $75.9 \pm 7.6$ & $\mathbf{5 2 . 5} \pm 5.2$ & $\mathbf{4 1 . 8} \pm 4.2$ & $\mathbf{3 7 . 5} \pm 3.7$ & $\mathbf{2 2 . 9} \pm 2.2$ & $\mathbf{1 6 . 5} \pm 1.6$ & $\mathbf{1 2 , 1} \pm 1.2$ \\
\hline & PCB167 & $\mathbf{5 0 . 7} \pm 5.1$ & $35.1 \pm 3.4$ & $27.7 \pm 2.8$ & $\mathbf{2 4 . 9} \pm 2.5$ & $\mathbf{1 0 . 5} \pm 1.0$ & $\mathbf{9 . 6} \pm 0.9$ & $\mathbf{8 . 1} \pm 0.7$ \\
\hline 7 & PCB180 & $\mathbf{1 6 4 . 9} \pm 14.3$ & $\mathbf{1 3 1 . 6} \pm 13.2$ & $\mathbf{1 1 5 . 1} \pm 11.5$ & $\mathbf{1 0 3 . 9} \pm 10.3$ & $\mathbf{9 7 . 3} \pm 9.7$ & $\mathbf{8 4 . 8} \pm 8.2$ & $66.7 \pm 6.6$ \\
\hline \multicolumn{2}{|c|}{$\Sigma$ PCB (ident.) } & $13153.9 \pm 657.7$ & $\mathbf{8 0 7 4 . 2} \pm 403.6$ & $\mathbf{5 7 7 0 . 3} \pm 288.4$ & $4702.2 \pm 235.0$ & $\mathbf{3 1 9 5 . 3} \pm 159.7$ & $\mathbf{2 3 9 5 . 0} \pm 119.7$ & $1650.6 \pm 82.5$ \\
\hline \multicolumn{2}{|c|}{$\begin{array}{l}\% \text { PCB (ident.) } \\
\text { biodegradation }\end{array}$} & & 38.6 & 56.1 & 64.3 & 75.7 & 81.8 & 87.5 \\
\hline
\end{tabular}

the PCB28 content was reduced from $2152.8 \mu \mathrm{g} / \mathrm{kg}$ d.m. to $539.5 \mu \mathrm{g} / \mathrm{kg}(74.9 \%)$ - Soil G2, 336,1 $\mu \mathrm{g} / \mathrm{kg}$ d.m. (84.4\%) - Soil G3, 217,5 $\mu \mathrm{g} / \mathrm{kg}$ d.m. (89.9\%) - Soil G4, 136,5 $\mu \mathrm{g} / \mathrm{kg}$ d.m. (93.7\%) - Soil G5, $90.0 \mu \mathrm{g} / \mathrm{kg}$ d.m. (95.8\%) - Soil G6. The biodegradation degree of tetrachlorobiphenyls upon inoculation with the biopreparation IN-3 carried out under ex-situ conditions was as follows: after 2 months $58.6 \%$ (PCB52) and 66.9\% (PCB77), after 4 months $-76.5 \%$ (PCB52) and $81.4 \%$ (PCB77), and after 6 months $-88.3 \%$ (PCB52) and 91.6\% (PCB77). The amount of pentachlorobiphenyls decreased within the range of 53.1-50.0\% (2 months), $73.4-72.3 \%$ (4 months), and $86.4-86.0 \%$ (6 months), while the reduction of PCB101 was: $47.5 \%, 69.9 \%$, and $83.6 \%$, respectively. After 2, 4, and 6 months of biodegradation the hexachlorobiphenyls content went down on average by: $45.1 \%, 50.7 \%$, and $83.9 \%$. However, biodegradation of di-ortho PCB congeners was less effective: PCB138 from 607.6 to $354.4 \mu \mathrm{g} / \mathrm{kg}$ d.m. (41.7\%) after 2 months, to $206.2 \mu \mathrm{g} / \mathrm{kg}$ d.m. (66.1\%) after 4 months, and to $113.8 \mu \mathrm{g} / \mathrm{kg}$.m. (81.3\%) after 6 months, while that of PCB156 from $145.6 \mu \mathrm{g} / \mathrm{kg}$ d.m. to $79,8 \mu \mathrm{g} / \mathrm{kg}$ d.m. (45.2\%), $45.0 \mu \mathrm{g} / \mathrm{kg}$ d.m. (69.1\%), and to $23.4 \mu \mathrm{g} / \mathrm{kg}$ d.m. (83.9\%), respectively. The content of PCB1 80 congener most difficult to biodegrade after 6 months of the biodegradation was reduced from $164.9 \mu \mathrm{g} / \mathrm{kg}$ d.m. to $66.7 \mu \mathrm{g} / \mathrm{kg}$ d.m., which was $59.6 \%$ (Table 1). Figure 4 presents chromatograms of identified PCB congeners separation in the sample of starting (raw) soil (soil G) and during the biodegradation (soil G3 and soil G6).

The obtained results of chromatographic analyses show that with an increasing number of chlorine atoms in a PCB molecule the biodegradation degree decreases. Low-chlorinated biphenyls (up to 4 chlorine atoms in a molecule) easily biodegrade as a result of inoculation with the biopreparation IN-3, while the biodegradation of highly-chlorinated biphenyls (more than 4 chlorine atoms in a molecule) proceeds definitely slower (Borja et al., 2005; Vasilyeva and Strijakowa, 2007). Also the spatial structure of a molecule affects the biodegradation efficiency. PCB congeners having in a biphenyl ring 2 or more chlorine atoms in the di-ortho position are more difficult to biodegrade (in the studied soil): PCB52, PCB101, PCB138, PCB153, and PCB180), than the non-ortho or mono-ortho PCB congeners (Vasilyeva and Strijakowa, 2007, Petrić et al., 2011). In turn, polychlorinated biphenyls, in which chlorine atoms exist only in one phenyl ring, biodegrade easier (Borja et al., 2005).

Furthermore, it should be remembered that in the analyzed soil, apart from the increased PCB content, there were also high TPH concentrations. Therefore, the presence of TPH in the studied soil can significantly affect the course of $\mathrm{PCB}$ bioremediation. Research on the coexistence of PCB and TPH in soil and its impact on the bioremediation process constitute an interesting research area and will be the subject of further considerations. 

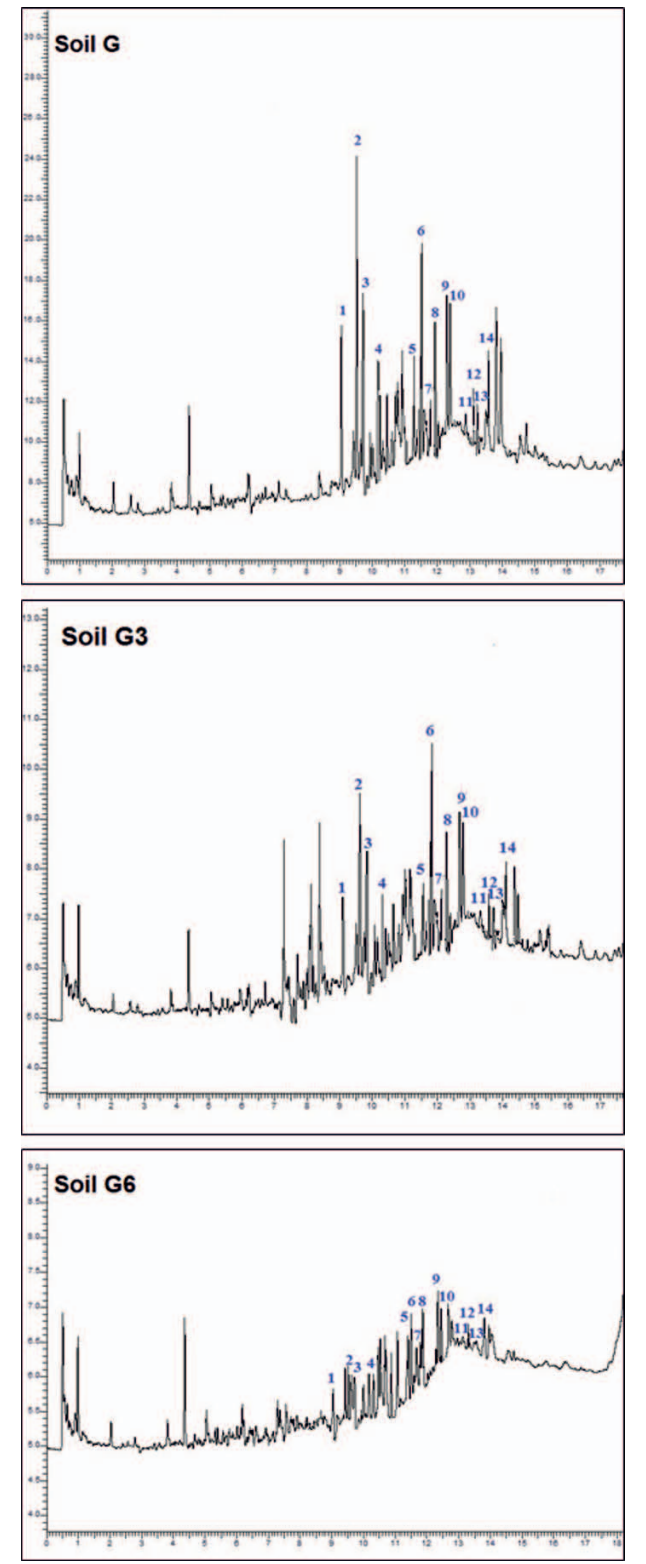

Fig. 4. Chromatograms of separation of polychlorinated biphenyls in starting soil samples (soil G), after 3 months of biodegradation (soil G3) and 6 months of biodegradation (soil G6). 1-PCB28, 2-PCB52, 3-PCB101, 4-PCB77, 5-PCB123, 6-PCB118, 7-PCB114, 8-PCB153, 9-PCB105, 10-PCB138, 11-PCB167, 12-PCB156, 13-PCB157, 14-PCB180

Rys. 4. Chromatogramy rozdziału polichlorowanych bifenyli w próbkach gleby wyjściowej (gleba G), po 3 miesiącach biodegradacji (gleba G3) i 6 miesiącach biodegradacji (gleba G6). 1-PCB28, 2-PCB52, 3-PCB101, 4-PCB77, 5-PCB123, 6-PCB118, 7-PCB114, 8-PCB153, 9-PCB105, 10-PCB138, 11-PCB167, 12-PCB156, 13-PCB157, 14-PCB180

\section{Toxicological assessment of the soil}

Pollution of the natural environment with harmful chemical compounds, including PCBs, contributes to permanent deterioration of the health state of living organisms. Therefore a comprehensive assessment of the soil quality should be based not only on the concentration of selected physical and chemical parameters, but should also include a bioindicative analysis, evaluating its toxic action on living organisms.

The Microtox test showed that successive lowering of polychlorinated biphenyls content resulted in the reduction of studied soil toxicity from $\mathrm{TU}=26.7$ (Soil G) to $\mathrm{TU}=6.1$ (Soil G6) (Fig. 5).

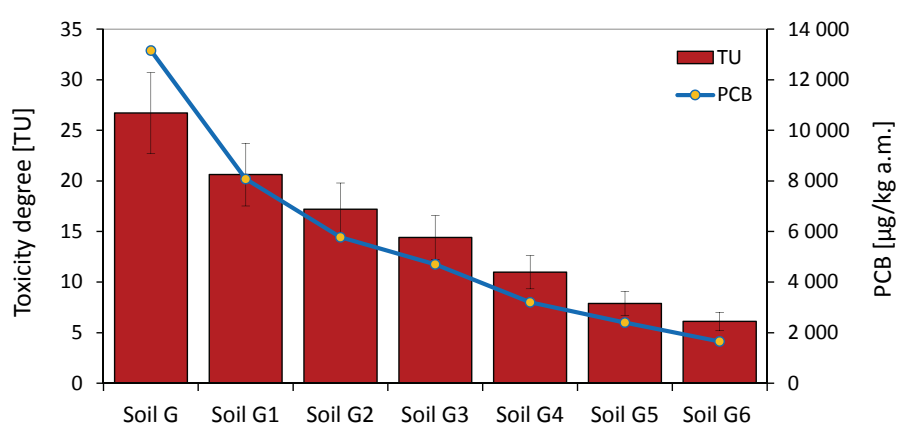

Fig. 5. Impact of polychlorinated biphenyls on soil toxicity (TU) Rys. 5. Wpływ polichlorowanych bifenyli na stopień toksyczności (TU) gleby

Performed toxicity tests of toxkit type (Phytotoxkit ${ }^{\mathrm{FM}}$ and Ostracodtoxkit $\mathrm{F}^{\mathrm{TM}}$ ) showed that Soil $\mathrm{G}$ (starting soil) featured high toxicity with respect to the applied test organisms.

In the Phytotoxkit ${ }^{\mathrm{FM}}$ toxicity test the amounts of germinated seeds in the starting soil sample were: for cress $-60 \%$, sorghum $-70 \%$, and mustard $-80 \%$, while the root growth inhibition ranged from 64.7 to $77.9 \%$. As a result of cleaning (inoculation with biopreparation IN-3) the amount of germinated seeds after 6 months of the biodegradation went up to $100 \%$, and the root growth inhibition was $11.9-17.4 \%$ (Fig. 6).

The Ostracodtoxkit $\mathrm{F}^{\mathrm{TM}}$ test performed on the starting soil sample showed mortality of Heterocypris incongruens bioindicators of approx. $65.0 \%$ and the ostracods growth inhibition of $69.3 \%$. Upon biodegradation the mortality of test organisms was reduced to $15.0 \%$ and the growth inhibition was $14.8 \%$ (Fig. 7).

The mutagenicity of the samples is indicated by the value of the mutagenicity index in the Ames test. Mutagenicity index is the ratio of test strains revertants number, which originated on the substrate without histidine (as a result of test strains contact with pollutants) to the number of spontaneous revertants. The carried out Ames mutagenicity test showed that the mutagenicity index in raw soil (Soil G) was 12.3, which indicates that the sample is mutagenic. In the soil sample after inoculation with biopreparation IN-3 after 3 months under ex-situ laboratory conditions a visible reduction of the mutagenicity index was obtained - to 6.5. The continuation of inoculation with the biopreparation IN-3 contributed to a further reduction of the mutagenicity index after 6 months to 1.5 , at which the sample is considered non-mutagenic (Fig. 8). 

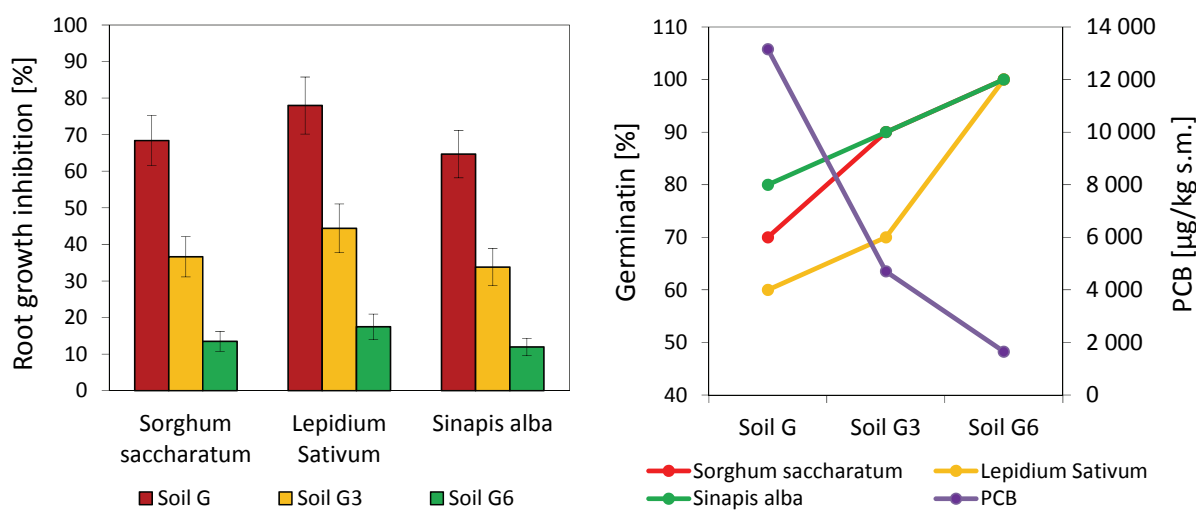

Fig. 6. Germination and inhibition of root growth in the Phytotoxkit test in soil G, G3 and G6 Rys. 6. Kiełkowanie oraz zahamowanie wzrostu korzeni w teście Phytotoxkit w glebie G, G3 i G6

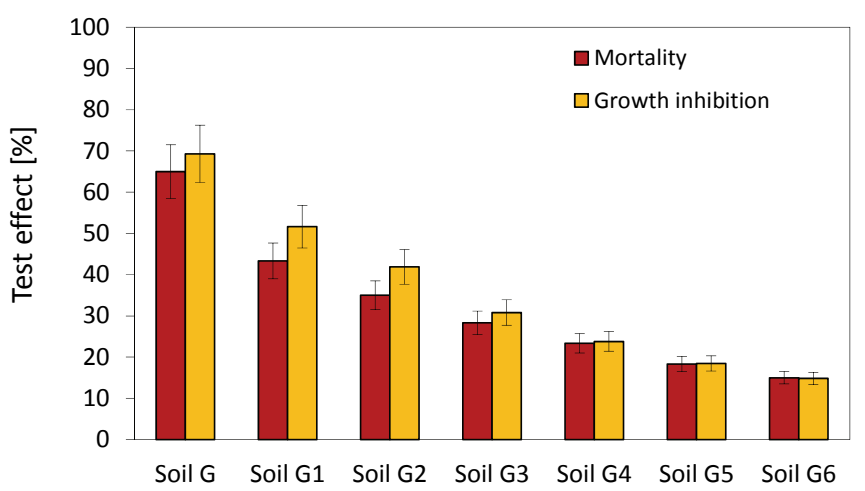

Fig. 7. Mortality and growth inhibition Heterocypris incongruens (Ostracodtoxkit $\mathrm{F}^{\mathrm{TM}}$ test) during biodegradation $(\mathrm{n}=6, \mathrm{p}<0.05)$

Rys. 7. Śmiertelność i zahamowanie wzrostu Heterocypris incongruens (test Ostracodtoxkit $\mathrm{F}^{\mathrm{TM}}$ ) w trakcie biodegradacji $(\mathrm{n}=6, \mathrm{p}<0,05)$
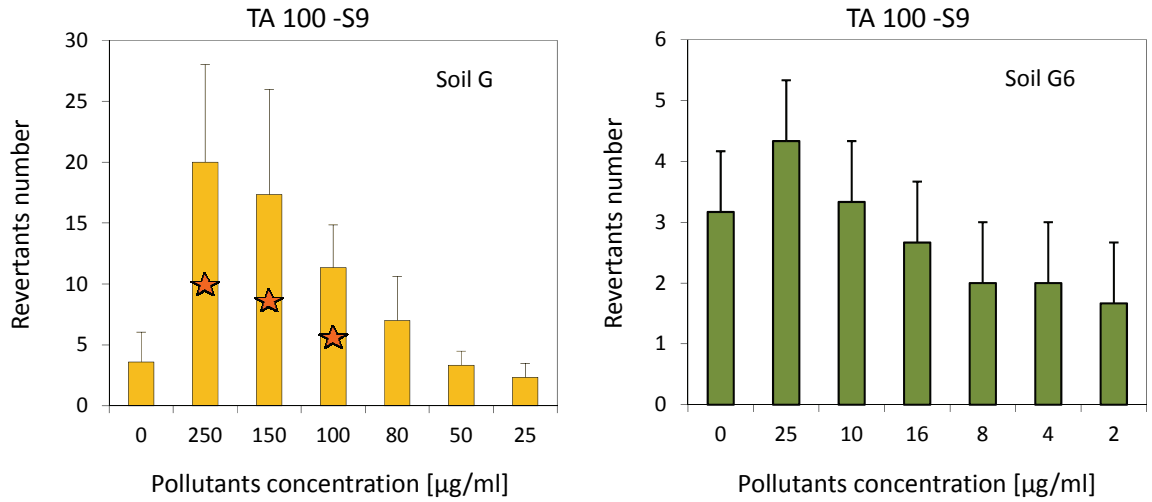

Fig. 8. Impact of polychlorinated biphenyls on the number of induced revertants - raw soil tested (Soil G) and soil after inoculation with biopreparation IN-3 (Soil G6) (repetition number $\mathrm{n}=3, \mathrm{p}<0.05$ )

Rys. 8. Wpływ polichlorowanych bifenyli na liczbę rewertantów indukowanych - testowana gleba surowa (Gleba G) oraz gleba po inokulacji biopreparatem (Gleba G6) (liczba powtórzeń $\mathrm{n}=3, \mathrm{p}<0,05$ ) composition of microorganisms (Passatore et al., 2014; Wu et al., 2017; Steliga et al., 2018a).

2. Chromatographic analysis enables qualitative and quantitative determination of individual PCB congeners during the process of soil cleaning (Wojtowicz and Jakubowicz, 2019). It enabled to determine biodegradability of individual groups of polychlorinated biphenyls, and hence more complete illustration of the biodegradation course.

3. Biodegradation of polychlorinated biphenyls depends on the number of chlorine atoms in a biphenyl ring and on the molecule structure. Low-chlorinated biphenyls (up to 4 chlorine atoms in a molecule) easily biodegrade as a result of inoculation with the biopreparation IN-3, while the biodegradation of highlychlorinated biphenyls (more than 4 chlorine atoms in a molecule) proceeds definitely slower, e.g. after a month the content of a congener with 3 chlorine atoms (PCB28) was reduced from 2152.8 to $1077.0 \mu \mathrm{g} / \mathrm{kg}$ d.m., which is $50.0 \%$, while of a congener with 7 chlorine atoms in the molecule (PCB180) from 164.9 to $131.6 \mu \mathrm{g} / \mathrm{kg}$ d.m., which is $20.2 \%$. PCB congeners having 2 or more chlorine atoms in the biphenyl ring in the ortho position are more difficult to biodegrade than non-ortho or mono-ortho PCB congeners; in turn, polychlorinated biphenyls in which chlorine atoms exist only in one phenyl ring are easier biodegradable (Borja et al., 2005; Vasilyeva and Strijakowa, 2007; Petrić et al., 2007).

\section{Summary}

1. Pollution biodegradation via bioaugmentation with a biopreparation depends on abiotic and biotic factors. They include: physical and chemical properties of the soil, xenobiotic concentration and structure, concentration of biogenic substances (nitrogen, phosphorus), temperature, oxygen content, humidity, $\mathrm{pH}$, quantitative and qualitative
4. A comprehensive assessment of the biodegradation effectiveness should be based not only on the concentration of selected physical and chemical parameters, but should also include a toxicological analysis. Toxicological tests allow simultaneous determination of harmful action of all substances present in the tested sample on selected live organisms, taking into account interactions occurring between all components of the tested system (Steliga et al., 2018b). 
The paper was written on the basis of the statutory work entitled: Bioremedation of soil polluted with polychlorinated biphenyls (PCBs) using modern biological and toxicological methods - the work of the Oil and Gas Institute - National Research Institute was commissioned by the Ministry of Science and Higher Education; order number: 0036/KE/2019/01, archive number: DK-4100-0026/2019/01.

\section{References}

Atago Y., Shimodaira J., Araki N., Othman N.B., Zakaria Z., Fukuda M., Futami J., Hara H., 2016. Identification of novel extracellular protein for PCB/biphenyl metabolism in Rhodococcus jostii RHA1. Bioscience, Biotechnology, and Biochemistry, 80(5): 1012-1019. DOI: 10.1080/09168451.2015.1127134.

Baran A., Tarnawski M., 2013. Phytotoxkit/Phytotestkit and Microtox ${ }^{\circledR}$ as tools for toxicity assessment of sediments. Ecotoxicology and Environmental Safety, 98: 19-27. DOI: 10.1016/j.ecoenv.2013.10.010.

Blanco-Moreno R., Sáez L.P., Luque-Almagro V.M., Roldán M.D., Moreno-Vivián C., 2017. Isolation of bacterial strains able to degrade biphenyl, diphenyl ether and the heat transfer fluid used in thermo-solar plants. New Biotechnology, 35: 35-41. DOI: 10.1016/j.nbt.2016.11.003.

Blinova I., Bityukova L., Kasemets K., Ivask A., Käkinen A., Kurvet I., Bondarenko O., Kanarbik L., Sihtmäe M., Aruoja V., Schvede H., Kahru A., 2012. Environmental hazard of oil shale combustion fly ash. Journal of Hazardous Materials, 229-230: 192-200. DOI: 10.1016/j.jhazmat.2012.05.095.

Borja J., Taleon D.M., Auresenia J., Gallardo S., 2005. Polychlorinated Biphenyls and Their Biodegradation. Process Biochemistry, 40: 1999-2013. DOI: 10.1016/j.procbio.2004.08.006.

Brzeszcz J., 2017. Drobnoustroje środowiskowe, zdolne do jednoczesnego rozkładu węglowodorów alifatycznych i aromatycznych - perspektywy wykorzystania w praktyce bioremediacji gleb zanieczyszczonych substancjami ropopochodnymi. Rozprawa doktorska, Wydziat Biologii i Nauk o Ziemi UJ.

Chakraborty J., Das S., 2016. Haracterization of the metabolic pathway and catabolic gene expression in biphenyl degrading marine bacterium Pseudomonas aeruginosa JP-11. Chemosphere, 144: 1706-1714. DOI: 10.1016/j.chemosphere.2015.10.059.

Chung S.Y., Maeda M., Song E., Horikoshij K., Kudo T., 1994. A Gram positive polychlorinated biphenyl degrading bacterium, Rhodococcus erythropolis strain TA421, isolated from a termite ecosystem. Bioscience, Biotechnology, and Biochemistry, 58(11): 2111-2113. DOI: 10.1271/bbb.58.2111.

Čvančarová M., Křesinová Z., Filipová A., Covino S., Cajthaml T., 2012. Biodegradation of PCBs by ligninolytic fungi and characterization of the degradation products. Chemosphere, 88(11): 1317-1323. DOI: 10.1016/j.chemosphere.2012.03.107.

Dudášová H., Lukáčová L., Murínová S., Puškárová A., Pangallo D., Dercová K., 2014. Bacterial strains isolated from PCBcontaminated sedimentsand their use for bioaugmentation strategy in microcosms. Journal of Basic Microbiology, 54: 253-260. DOI 10.1002/jobm.201200369.

Foucault Y., Durand M.J., Tack K., Schreck E., Geret F., Leveque T., Pradère P., Goix S., Dumat C., 2013. Use of ecotoxicity test and ecoscores to improve the management of polluted soils: case of a secondary lead smelter plant. Journal of Hazardous Materials, 246-247: 291-299. DOI: 10.1016/j.jhazmat.2012.12.042.

Furukawa K., Fujihara H., 2008. Microbial degradation of polychlorinated biphenyls: Biochemical and molecular features. Journal of
Bioscience and Bioengineering, 105(5): 433-449. DOI: 10.1263/ jbb.105.433.

Kania-Korwel I., Lehmler H.J., 2016. Toxicokinetics of chiral polychlorinated biphenyls across different species - a review. Environmental Science and Pollution Research, 23(3): 2058-2080.

Kim C-H., Lim D., Keum Y-S., 2016. Biodegradation Pathways of Polychlorinated Biphenyls by Soil Fungus Aspergillus Niger. The Korean Journal of Pesticide Science, 20(q): 7-13. DOI: 10.7585/ kjps.2016.20.1.7.

Lászlová K., Dudášová H., Olejníková P., Horváthová G., Velická Z., Horváthová H., Dercová K., 2018. The Application of Biosurfactants in Bioremediation of the Aged Sediment Contaminated with Polychlorinated Biphenyls. Water, Air, \& Soil Pollution, 229(219): 1-18. DOI: 10.1007/s11270-018-3872-4.

Leigh M.B., Prouzová P., Macková M., Macek T., Nagle D.P., Fletcher J.S., 2006. Polychlorinated Biphenyl (PCB)-Degrading Bacteria Associated with Trees in a PCB-Contaminated Site. Applied and Environmental Microbiology, 72(4): 2331-2342. DOI: 10.1128/AEM.72.4.2331-2342.2006.

Li H., Liu L., Lin C., Wang S., 2011. Plant uptake and in soil degradation of PCB-5 under varying cropping conditions. Chemosphere, 84: 943-949. DOI:10.1016/j.chemosphere.2011.06.007.

Liang Y., Martinez A., Hornbuckle K.C., Mattes T.E., 2014. Potential for Polychlorinated Biphenyl Biodegradation in Sediments from Indiana Harbor and Ship Canal. International Biodeterioration \& Biodegradation, 89: 50-57. DOI: 10.1016/j.ibiod.2014.01.005.

Lima T.M., Procópio L.C., Brandão F.D., Leão B.A., Tótola M.R., Borges A.C., 2011. Evaluation of bacterial surfactant toxicity towards petroleum degrading microorganisms. Bioresource Technology, 102(3): 2957-2964. DOI: 0.1016/j.biortech.2010.09.109.

Lu Y.F., Lu M., Peng F., Liao M.H., 2014. Remediation of polychlorinated biphenyl-contaminated soil by using a combination of ryegrass, arbuscular mycorrhizal fungi and earthworms. Chemosphere, 106: 44-50. DOI:10.1016/j.chemosphere.2013.

Lunt D., Evans W.C., 1970. The microbial metabolism of biphenyl. Biochemical Journal, 118(3): 54-55. DOI: 10.1042/bj1180054pb.

Maminidy-Pajany Y., Hamer B., Romeo M., Geret F., Galgani F., Durmisi E., Hurel C., Marmie N., 2011. The Toxicity of composted sediments from mediterranean ports evaluated by several bioassays. Chemosphere, 82(3): 62-69. DOI:10.1016/j. chemosphere.2010.10.005.

Mouhamadou B., Faure M., Sage L., Marcais J., Souard F., Geremia R.A., 2013. Potential of autochthonous fungal strains isolated from contaminated soils for degradation of polychlorinated biphenyls. Fungal Biology, 117(4): 268-274. DOI: 10.1016/j. funbio.2013.02.004.

Niyommaneerat W., Nakajima F., Tobino T., Yamamoto K., 2017. Development of a chronic sediment toxicity test using the benthic ostracod Heterocypris incongruens and their application to toxicity assessments of urban road dust. Ecotoxicology and Environmental Safety, 143: 266-274. DOI: 10.1016/j.ecoenv.2017.05.011.

Nwankwegu A.S., Orji M.U., Onwosi C.O., 2016. Studies on organic and in-organic biostimulants in bioremediation of diesel-contaminated arable soil. Chemosphere, 162: 148-156. DOI: 10.1016/j. chemosphere.2016.07.074.

Oh S.Y., Yoon H.S., Jeong T.Y., Kim S.D., 2015. Evaluation of remediation processes for explosive-contaminated soils: kinetics and Microtox ${ }^{\circledR}$ bioassay. Journal of Chemical Technology \& Biotechnology, 91(4): 928-937. DOI: 10.1002/ jctb.4658.

Oleszczuk P., Jośko I., Kuśmierz M., Futa B., Wielgosz E., Ligęza S., Pranagal J., 2014. Microbiological, biochemical and ecotoxicological evaluation of soils in the area of biochar production in 
relation to polycyclic aromatic hydrocarbon content. Geoderma, 213: 502-511. DOI: 10.1016/j.geoderma.2013.08.027.

Passatore L., Rossetti S., Juwarkar A.A., Massacci A., 2014 Phytoremediation and bioremediation of polychlorinated biphenyls (PCBs): State of knowledge and research perspectives. Journal of Hazardous Materials, 278: 189-202. DOI: 10.1016/j. jhazmat.2014.05.051

Pathiraja G., Egodawatta P., Goonetilleke A., Teo V.S., 2019. Effective degradation of polychlorinated biphenyls by a facultative anaerobic bacterial consortium using alternating anaerobic aerobic treatments. Science of The Total Environment, 659: 507-514. DOI: 10.1016/j.scitotenv.2018.12.385.

Petrić I., Hršak D., Fingler S., Vanćina E., Ćetković H., Kolara A.B., Kolić N.U., 2007. Enrichment and Characterization of PCBDegrading Bacteria as Potential Seed Cultures for Bioremediation of Contaminated Soil. Food Technology and Biotechnology, 45: 11-20.

Ponce B.L., Latorre V.K., González M., Seege M., 2011. Antioxidant compounds improved PCB-degradation by Burkholderia xenovorans strain LB400. Enzyme and Microbial Technology, 9(6-7): 509-516. DOI: 10.1016/j.enzmictec.2011.04.021.

Shleeva M.O., Bagramyan K., Telkov M.V., Mukamolova G.V., Young M., Kell D.B., Kaprelyants A.S., 2002. Formation and resuscitation of 'nonculturable' cells of Rhodococcus rhodochrous and Mycobacterium tuberculosis in prolonged stationary phase. Microbiology, 148: 1581-1591.

Shumkova E.S., Olsson B.E., Kudryavtseva A.V., Plotnikova E.G., 2015. Draft genome sequence of Rhodococcus ruber strain P25, an active polychlorinated biphenyl degrader. Genome Announcements, 3(5). DOI: 10.1128/genomeA.00990-15.

Siebielska I., 2009. Kinetyka przemian polichlorowanych bifenyli w czasie kompostowania. Rocznik Ochrona Środowiska, 11: 473-483.

Sierra I., Valera J.L., Marina M.L., Laborda F., 2003. Study of the biodegradation process of polychlorinated biphenyls in liquid medium and soil by a new isolated aerobic bacterium (Janibacter sp.). Chemosphere, 53(6). DOI: 10.1016/S0045-6535(03)00418-1.

Siracusa G., Becarelli S., Lorenzi R., Gentini A., Di Gregorio S., 2017. PCB in the environment: bio-based processes for soil decontamination andmanagement of waste from the industrial production of Pleurotus ostreatus. New Biotechnology, 39: 232-239. DOI:10.1016/j.nbt.2017.08.011

Slater H., Gouin T., Leigh M.B., 2011. Assessing the potential for rhizoremediation of $\mathrm{PCB}$ contaminated soils in northern regions using native species. Chemosphere, 84: 199-206. DOI: 10.1016/j. chemosphere.2011.04.058.

Steliga T., Jakubowicz P., Kapusta P., 2012. Changes in toxicity during in situ bioremediation of weathered drill wastes contaminated with petroleum hydrocarbons. Bioresource Technology, 125: 1-10. DOI: org/10.1016/j.biortech.2012.08.092.

Steliga T., Jakubowicz P., Kapusta P., Kluk D., 2018a. Badania biodegradacji zestarzałych odpadów wiertniczych zanieczyszczonych substancjami ropopochodnymi. Przemyst Chemiczny, 97(10): 1666-1675. DOI: 10.151999/62.2018.10.7.

Steliga T., Jakubowicz P., Wojtowicz K., Kluk D., 2018b. Zastosowanie testów toksykologicznych w przemyśle naftowym. Nafta-Gaz, 9: 684-689. DOI: 10.18668/NG.2018.09.07.

Steliga T., Kluk D., 2019. Potential of Helianthus annuus for phytoremediation of lead, zinc, total petroleum hydrocarbons (TPH) and polycyclic aromatic hydrocarbons (PAHs) contaminated soil. Nafta-Gaz, 7: 379-387. DOI: 10.18668/NG.2019.07.01.
Stella T., Covino S., Čvančarová M., Filipová A., Petruccioli M., D'Annibale A., Cajthaml T., 2017. Bioremediation of long-term PCB-contaminated soil by white-rot fungi. Journal of Hazardous Materials, 324(B): 701-710. DOI:10.1016/j.jhazmat.2016.11.044.

Suenaga H., Fujihara H., Kimura N., Hirose J., Watanabe T., Futagami T., Goto M., Shimodaira J., Furukawa K., 2017. Insights into the genomic plasticity of Pseudomonas putida KF715, a strain with unique biphenyl-utilizing activity and genome instability properties. Environtal Microbiology Reports, 5: 589-598. DOI: 10.1111/1758-2229.12561.

Suyamud B., Inthorn D., Panyapinyopol B., Thiravetyan P., 2018. Biodegradation of Bisphenol A by a Newly Isolated Bacillus megaterium Strain ISO-2 from a Polycarbonate Industrial Wastewater. Water, Air \& Soil Pollution, 229-348. DOI:10.1007/ s11270-018-3983-y.

Teng Y., Li X., Chen T., Zhang M., Wang X., Li Z., Luo Y., 2016. Isolation of the PCB-degrading bacteria Mesorhizobium sp. ZY1 and its combined remediation with Astragalus sinicus L. for contaminated soil. International Journal of Phytoremediation, 18(2): 141-149. DOI: 10.1080/15226514.2015.1073667.

Trusz-Zdybek A., Szymczycha-Madeja A., Traczewska T.M., Piekarska K., 2012. Zastosowanie systemu microtox w bioindykacji próbek środowiskowych. Kosmos, 61(3): 417-423.

Vasilyeva G.K., Strijakowa E.R., 2007. Bioremediation of soils and sediments contaminated by polychlorinated biphenyls. Microbiology, 76(6): 639-653. DOI: 10.1134/S002626170706001X

Vijay U., Gupta S., Mathur P., Suravajhala P., Bhatnagar P., 2018. Microbial Mutagenicity Assay: Ames Test. Bio-protocol, 8(6): 1-15. DOI:10.21769/BioProtoc.2763.

Wang X., Teng Y., Luo Y., Dick R.P., 2016. Biodegradation of 3, 3, 4, 4- tetrachlorobophenyl by Sinorhizobium meliliti NM. Bioresource Technology, 201: 261-268. DOI: 10.1016/j.biortech.2015.11.056.

Wojtowicz K., Jakubowicz P., 2019. Opracowanie metodyki oznaczania polichlorowanych bifenyli w próbkach gleb. Nafta-Gaz, 7: 420-429. DOI: 10.18668/NG.2019.07.06.

Wu M., Li W., Dick W.A., Ye X., Chen K., Kost D., Chen L., 2017. Bioremediation of hydrocarbon degradation in a petroleumcontaminated soil and microbial population and activity determination. Chemosphere, 169: 124-130. DOI: 10.1016/j. chemosphere.2016.11.059.

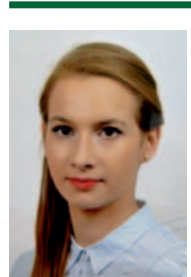

Katarzyna WOJTOWICZ M.Sc.

Assistant at the Department of Reservoir

Fluid Production Technology

Oil and Gas Institute - National Research Institute

25 A Lubicz St.

31-503 Krakow

E-mail: katarzyna.wojtowicz@inig.pl

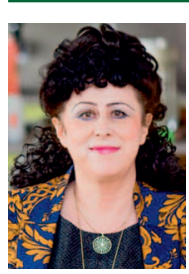

Teresa STELIGA Ph.D. Eng.

D.Sc. Associate Professor, Department of Reservoir Fluid Production Technology

Oil and Gas Institute - National Research Institute

25 A Lubicz St.

31-503 Krakow

E-mail: teresa.steliga@inig.pl 